Pamiętnik Literacki 2015, 2, s. 185-189

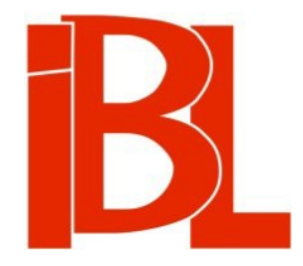

\title{
Stefan Żeromski wobec jubileuszu Lwa
}

\author{
Tołstoja
}

Zdzisław Jerzy Adamczyk 


\section{STEFAN ŻEROMSKI WOBEC JUBILEUSZU LWA TOŁSTOJA}

Publikowany tutaj nieznany artykuł Stefana Żeromskiego powstał w związku z uroczyście w Rosji obchodzoną 80 rocznicą urodzin Lwa Tołstoja. $Z$ tej okazji niektóre pisma rosyjskie zdecydowały się wydać specjalne numery - i do tych okolicznościowych numerów zamówiły u rosyjskich i europejskich myślicieli, uczonych i literatów wypowiedzi na temat roli i znaczenia twórczości i działalności Tołstoja. Prośby o nadesłanie takich opinii kierowano także do polskich autorów. Wiadomo, że dla petersburskiego dziennika „Riecz” o Tołstoju napisał Bolesław Prus ${ }^{1}$, a na apel moskiewskich „Russkich wiedomosti” krótkimi szkicami zareagowali Henryk Sienkiewicz $^{2}$ oraz Eliza Orzeszkowa ${ }^{3}$. Nie było dotąd wiadomo, iż $z$ podobną prośba redakcja ta zwróciła się i do Stefana Żeromskiego.

W Bibliotece Narodowej w Warszawie zachował się list do Żeromskiego - w dniu 7/20 VIII 1908 wysłany do niego w imieniu redakcji „Russkich wiedomosti” przez profesora Dmitrija Nikołajewicza Anuczina. List napisany został po polsku i brzmiał następująco:

Czcigodny Panie! Redakcja dziennika „Russkije wiedomosti”, pragnąc uczcić jubileusz Leona Tołstoja, zamierza poświęcić wielkiemu pisarzowi specjalny numer, w którym będą pomieszczone artykuły i odezwy o Tołstoju koryfeuszów europejskiej myśli, literatury i sztuki. W tym celu redakcja zwraca się również do Ciebie, Czcigodny Panie, z prośbą, byś zechciał skreślić i nadesłać nam bodaj kilkanaście wierszy o naszym i zarazem wszechświatowym wielkim pisarzu. Jubileuszowy numer ma wyjść w dniu 28 sierpnia / 10 września br. Racz, Czcigodny Panie, przyjąć wyrazy szczerego i głębokiego szacunku i poważania ${ }^{4}$.

1 B. Prus, Po powodu jubileja. „Riecz” 1908, nr 217, z 11/24 IX. Polski tekst znany z omówienia i obszernych fragmentów przedrukowanych w „Dzienniku Kijowskim” (1908, nr 200, z 27 IX): Bolesław Prus o Totstoju.

2 G. Si e n ki ew i c z, Lew Tołstoj. (Pieriewod s rukopisi). „Russkije wiedomosti” 1908, nr 199, z 28 VIII/ 10 IX. Polską wersje publikowano kilkakrotnie w prasie - zob. np. Sienkiewicz o Tołstoju. „Czas” 1908, nr 204, z 5 IX.

3 E. Orzeszko, Lew Tołstoj. (Piśmo $w$ redakcyju. Pieriewod s polskago). „Russkije wiedomosti” 1908, nr 207, z 6/19 IX. Polski przekład: Orzeszkowa o Tołstoju. W: E. Orzes z k ow a, Pisma krytycznoliterackie. Zebrał, oprac. E. J a n k ow s ki. Wrocław 1959, s. 490-491.

4 D. N. Anuczin, list do S. Żeromskiego, z 7/20 VIII 1908. Bibl. Narodowa, rkps 17 218, t. 1. List napisany został na maszynie - zapewne przez kalkę i w paru egzemplarzach. Nie znamy treści zaproszenia, jakie redakcja wysłała do Sienkiewicza, wiadomo natomiast, jaki list otrzymała Orzeszkowa, gdyż jego fragmenty zacytował w komentarzu edytorskim wydawca Pism krytycznoliterackich. Do Orzeszkowej redaktor „Russkich wiedomosti” - także 7/20 VIII 1908 - skierował m.in. takie słowa: „redakcja zwraca się również do Ciebie, Czcigodna Pani, z prośbą, byś zechciała skreślić i nadesłać nam bodaj kilkanaście wierszy o naszym i zarazem wszechświatowym wielkim pisarzu”. 
Również w Bibliotece Narodowej zachowały się dwie brulionowe wersje artykułu, który powstał najprawdopodobniej w odpowiedzi na zaproszenie redakcji „Russkich wiedomosti”. Teksty te znajdują się w zbiorku autografów Żeromskiego (sygn. akc. 13 679), zakupionym od Moniki Żeromskiej w roku 1992 i opatrzonym tytułem Zielony kajet.

Te dwie brulionowe wersje artykułu (obie niezatytułowane) są objętościowo nierówne. Wcześniejsza zajmuje 6 kart białego papieru w linie - obustronnie zapisanych niebieską kredką; pismo tutaj wyraźne, z nielicznymi poprawkami dokonanymi tą samą niebieską kredką lub czarnym atramentem; duże fragmenty tekstu (prawie cała karta 2 i 3) przekreślone. Układ tekstu niezbyt przejrzysty; widać, że porządek zdań i myśli formował się w trakcie pisania: na początku mowa jest o tym, iż literatura rosyjska przechodziła i przechodzi obojętnie wobec potwornych krzywd, jakie ze strony państwa rosyjskiego spotykały i spotykają polski naród, dalej następuje pochwała twórczości literackiej Tołstoja i niezwykle wysoka ocena Anny Kareniny, potem wracają sprawy ogólniejsze - spostrzeżenie, że literatura polska i sprawa polska Rosjan nie interesują, przypomnienie, iż „wielki pisarz Dostojewski smagał nas niezgorzej" - i znowu słowa podziwu dla twórczości Tołstoja.

Druga wersja artykułu jest i skromniejsza objętościowo, i myślowo bardziej zdyscyplinowana. Zajmuje 4 karty białego papieru w kratkę, zapisane obustronnie czarnym atramentem. Artykuł o Tołstoju wypełnia karty 1-3v; na karcie 4 znajdują się 3 jednozdaniowe informacje o bohaterach utworów Tołstoja (nie mieszczące się w strukturze artykułu); karta 4v została pusta. Zapis ten, zbliżony do czystopisowego, zaczyna się pismem starannym, niemal bez skreśleń i poprawek, potem wszakże, na kartach 2-3v, tekst jest w kilku miejscach przerabiany i uzupełniany.

Nie wiadomo, czy Żeromski przygotował jakiś następny czystopis tej swojej jubileuszowej wypowiedzi i czy go wysłał do Moskwy. W numerze 199 „Russkich wiedomosti” z 28 VIII 1908, prawie w całości poświęconym Tołstojowi, opinii Żeromskiego nie ma, nie pojawiła się też - ani w tym numerze, ani w następnych żadna informacja, $z$ której wynikałoby, iż w jakikolwiek sposób odpowiedział on na zaproszenie redakcji. Nie da się rozstrzygnacé zatem, czy Żeromski, przygotowawszy swój artykuł prawie w zupełności, zrezygnował z nadania mu definitywnej wersji czystopisowej i ostatecznie go do redakcji „Russkich wiedomosti” nie wysłał, czy też zrobił to, natomiast redakcja, ze względu na antyrosyjską wymowę polityczną tekstu, zdecydowała się go nie drukować. Drugie przypuszczenie jest jednak tylko spekulacją, której nie można wesprzeć żadnymi dowodami.

Nawet jeśli Żeromski zrezygnował $\mathrm{z}$ druku swej wypowiedzi, to - wydaje się zasługuje ona na publikację. I to $z$ kilku względów.

Po pierwsze dlatego, że jest myślowo i pisarsko dopracowana niemal jak czystopisowy tekst finalny. Po wtóre - ponieważ Żeromski w swym sposobie myślenia o literaturze rosyjskiej i polsko-rosyjskich stosunkach literackich dość istotnie różni się od Prusa, Sienkiewicza i Orzeszkowej, co stwarza okazję do wyśledzenia nie tylko indywidualnych różnic między nimi, ale być może także odmienności międzypokoleniowych. Po trzecie wreszcie - gdyż autor Syzyfowych prac daleko wykracza poza ramy refleksji na temat literatury i jej miejsca w świecie wartości humanistycznych, nie ogląda się na poprawność, nie waha się mówić o interesach politycznych i konfliktach narodowych. 
Już w roku 1892, w jednym ze swych pierwszych tekstów publicystycznych, gdy dla krakowskiej „Nowej Reformy” pisał obszerne omówienie świeżo wówczas wydanej w Rosji powieści N. Pokrowskiego Blednow, której bohater gorliwie przykłada ręki do ucisku narodowego i rusyfikacji w Warszawie, zwrócił Żeromski uwagę, że literatura rosyjska, nawet ta buntująca się przeciw niesprawiedliwości i krzywdzie słabych, ze zdumiewająca obojętnością przechodzi obok krzywd i nieprawości spadających na naród polski. Na początku tamtego artykułu napisał:

Ci nawet spomiędzy beletrystów rosyjskich, którzy szlachetnie walczą pod hasłem sprawiedliwości społecznej i humanizmu, nie zdradzają bynajmniej współczucia i sympatii względem idei podtrzymujących oddech narodu polskiego. $Z$ wyjątkiem jednego bodaj Włodzimierza Sołowjowa, śmiało i bezwzględnie nawołującego społeczeństwo rosyjskie do wymierzenia sprawiedliwości skrzywdzonej Polsce (Kwestia nacjonalizmu $w$ Rosji ${ }^{5}$ ) - nie można wskazać żadnego pisarza, który by stawał w obronie naszej, wobec niezliczonej zgrai prokuratorów niszczenia i wynaradawiania. Genialny melancholik północy, Iwan Turgieniew, mówił o sobie umierając, że był zawsze prawdiw i czestien (prawdomówny i szlachetny) - miał jednak tyle tej szlachetności, że pisał broszury popierające system wynaradawiania w Królestwie. Wprawdzie szkicował czasami tendencyjnie dodatnie sylwetki Polaków i Polek (Kwieciński w powieści Stiepnoj Korol Lir, bohaterka pow[ieści] Now'), lecz są to raczej kontrasty, pomysły przygodne i środki artystyczne do oświetlenia niedołęstwa lub małostkowości w postaciach rdzennie rosyjskich. Dostojewski - ten mistyk altruizmu, poeta litości, jak go nazywa Brandes, nienawidził Polaków nie gorzej od Katkowa i wyszydzał wady tych nawet, którzy ginęli w kopalniach sybirskich. Szczedrin - najbardziej może oryginalny, niedoceniony pisarz naszego wieku, nieskazitelny rzecznik praw człowieka, daleko widzący mędrzec, chłostał aż do zaciekłości swym dowcipem, subtelniejszym bez wątpienia niż dowcip Dickensa i zjadliwszym niż dowcip Heinego, ten „szereg kolosalnych nieporozumień”, jakim według niego jest Rosja współczesna - dla nas jednak nie miał w swym niewyczerpanym arsenale ani jednej skałki ${ }^{6}$.

W 16 lat później, w artykule przygotowywanym z okazji jubileuszu Lwa Tołstoja, zamierzał Żeromski oskarżenie to powtórzyć, ale nie (jak w roku 1892) w gazecie wydawanej w Krakowie, lecz w jednym $z$ największych dzienników rosyjskich. Oto „wyczytany” $z$ brulionu tekst tego artykułu?:

\section{[JUBILEUSZ LWA TOŁSTOJA]}

Pracownicy na polu literatury polskiej, należący do tego pokolenia co piszący te słowa, znają dobrze literaturę rosyjska. Można nawet, nie popełniając przesady, powiedzieć, że znają literaturę rosyjską lepiej, bezwzględniej niż Rosjanie. Powziąwszy znajomość języka za dni dzieciństwa i młodości w sposób przymusowy, jak gdyby przez zastrzykiwanie bolesne tego języka w krew, w mózg, w serce i nerwy, oplecione nim mając jak powrozem trudy swe, prace, zamiary i marzenia, zakute w ten język jak w kajdany przez całe życie - zgłębiło to

5 Mowa o wydanej w Petersburgu w r. 1888 książce rosyjskiego filozofa, teologa i poety W. S oł o wjow a (1853-1900) Nacyonalnyj wopros $w$ Rossii. Autor pisał tam m.in. o historycznych winach Rosji wobec Polski oraz o potrzebie pojednania Rosjan i Polaków.

$6 \quad$ M. E., Sędzia - „Obrusitiel”. „Blednow”. Powieść. Napisat N. Pokrowski, Petersburg 1891. „Nowa Reforma" 1892, nr 83, z 10 IV. Przedruk fragmentów w tomie: S. Że r o m s ki, Elegie i inne pisma literackie i społeczne. Oprac. W. B o r o w y. Warszawa-Kraków 1928, s. 192-193.

$7 \quad$ Nie rejestruje się tutaj jedno- ani parowyrazowych skreśleń czy nadpisań przedstawiających proces dochodzenia autora do ostatecznego (przynajmniej na tym etapie pracy) kształtu artykułu, oznacza się natomiast miejsca, w których miały się w tekście pojawiać jakieś uzupełnienia, może jakieś nowe myśli, nowe treści, ale nie zostały przez autora wprowadzone. Pisownię i interpunkcję zmodernizowano. 
pokolenie piszących twórczość rosyjską do rdzenia, ma możność spoglądać na nią z góry i z dołu, twarzą w twarz i z ukosa - słowem: zgoła krytycznie.

Niezmierzony jest rozmiar krzywdy, którą zadał naród rosyjski narodowi polskiemu. Nie krew wylana na polach walk, nie tłumy zadręczone w katorgach są tej krzywdy wyrazem, lecz najokrutniejsza jej miara jest zduszenie polskiej siły życia przez rosyjską przemoc. Polska jest jak brzoza żywa, którą przemoc rosyjska zgięła, a gałęzie jej i pień przywaliła nieudźwignioną góra gliny. Wszystkie pieśni wielkiej poezji polskiej, wszystkie ${ }^{8}$ nieśmiertelne żale nad ojczyzną Mickiewicza, Słowackiego, Norwida i Wyspiańskiego nie zdołały i nie zdołają wyrazić tej straty, jaką poniósł i świat, i my przez tyloletnie nasze zawalenie gliną.

Literatura rosyjska, naszemu pokoleniu tak doskonale i ze wszech stron znana, nie westchnęła nigdy nad drzewem naszego żywota, nie zasmuciła się nigdy obrazem naszego nieszczęścia. Dola polska, sztuka i literatura jest dla literatury rosyjskiej nieznana i obca ${ }^{9}$. Nie piszę tych słów w chwili tak dla pisarstwa rosyjskiego uroczystej z zamiarem wynurzenia skargi. Przeciwnie - jeżeli wolno tu wyrazić osobisty pogląd - znajduję w tym szczególną pociechę i ulgę, że sztuka polska w dwu jej przejawach, w poezji i malarstwie, z pewnością stojąca na wielkiej wysokości - jest przez świat nie znana, zapomniana, istnieje tylko dla nas samych - zapomnianego przez świat narodu.

Wielki pisarz i wielki człowiek, któremu Rosja hołd dziś składa i przed którym świat czoło pochyla, nie schlebiał nam, gdyż nie schlebiał nikomu i niczemu na świecie. Patrzył on przez naszą mogiłę i przez nasze ruiny w swoją dal. Jego pisma były dla nas zakazane na równi z pismami naszych nieśmiertelnych poetów. Chodziły nasze dusze młodociane w jego dal. A choć, przezwyciężywszy jego urok do cna, poszliśmy każdy w swą dal swoją własną drogą, nie przestaliśmy go czcić w duchu i prawdzie. Twórczość jego jest jak tajna dolina kwiecista w skałach jałowych gór ${ }^{10}$. On zaś sam, pisarz, jest jak fenomen przyrody - sam dla siebie, jedyny, człowiek przemożny. Imię jego znaczy to samo co słowo „męstwo”.

Wychodził w życiu swym naprzeciwko wszelkich uznanych prawd, zakorzenionych wierzeń, naprzeciwko potęg, rozsiadłych na szczytach i wśród tłumów. Stał się chorążym walczącym w łonie ${ }^{11}$ ludzkości o prawo człowieka. Stał się ucieleśnionym Laonem, odchylającym z uśmiechem płaszcz i nastawiającym piersi, z pieśni wielkiego Anglika ${ }^{12}$.

Cześć wieczna nieugiętej jego cnocie, cześć jego samotnym pracom i cześć męstwu zastawniczemu $^{13}$ za prawa człowieka ${ }^{14}$.

Abstract

\section{ZDZISŁAW JERZY ADAMCZYK Kielce}

\section{STEFAN ŻEROMSKI AND LEO TOLSTOY'S JUBILEE}

Published here is an unknown Stefan Żeromski's statement on the occasion of Leo Tolstoy's eightieth birthday celebrated in the year 1908 in Russia. Following the Russian papers request, opinions about

Po tym słowie jeden wyraz nie odczytany.

Po tych słowach przekreślone początki zdań: „Jest to wypadek najlepszy, bywa bowiem, że wielki pisarz Dostojewski”; „Można bez przesady powiedzieć, że wyrazicielem”; „Wystarczy wymienić”.

W tym miejscu w tekście znak, że coś zostanie tutaj dodane, ale takiego uzupełnienia brak.

Lekcja niepewna.

Mowa o bohaterze poematu P. B. Shelleya Laon and Cythna.

zastawniczy (przestarz.) - oddawany w zastaw.

Na k. 4 brulionu zdania, które nie zostały przez autora włączone do artykułu: „Piotr Bezuchow wzięty do niewoli wybuchający szalonym śmiechem z nieprzyjaciół, którym się wydaje, że jego ducha wolnego wzięli do niewoli”; „Bohater Woskriesienija schodzacy z wolna po stopniach dantejskiego piekła”; „Ów gospodarz ogrzewający ciałem swym kostniejące zwłoki parobka”. 
Tolstoy's role and place in European literature were sent by, inter alia, Bolesław Prus, Eliza Orzeszkowa, Henryk Sienkiewicz, and their statements were published in the Russian press. Żeromski also prepared his opinion, but it was not published since it fundamentally differed from the opinions by the authors mentioned above. Żeromski sees and values the greatness of Tolstoy's works though he regrets that Tolstoy, showing his sensitivity to harm and injustice and defending humanistic values, fails to notice, as generally Russian writers did, the multitude of harm and misfortunes the Polish nation suffered from Russian captivity and oppression. 